\title{
PATERNALISME DALAM TINDAKAN MEDIS
}

\author{
Dionisius Felenditi
}

\author{
Bagian Filsafat Fakultas Ilmu Pendidikan Universitas Negeri Manado \\ Dosen luar biasa Filsafat-Etika Fakultas Kedokteran Universitas Sam Ratulangi Manado
}

\begin{abstract}
In an ethical context, paternalism means any act that limits someone's freedom, without his/her consent, for the purpose of either preventing the person from doing himself any harm, or carrying out something positive in a way that can not be achieved by himself/herself. The principle of paternalism must be distinguished from the harm principle. The principle of paternalism says that one's freedom may be limited if one will inflict the harm on oneself due to one's attitude, or will not be able to achieve something beneficial for himself/herself. Meanwhile, the harm principle says that someone's freedom may be limited if the purpose is to protect another person from the harm inflicted by the first party. In medical service sector, paternalism causes conflicts between the principle of beneficence and the principle of autonomy. This is evident if a doctor takes a certain medical action based on the principle of beneficence without giving any information to the competent patient, or the doctor gives the information only to the family. In this situation, there is no informed consent. However paternalism can not cause conflict between these two ethical principles if the patient is not autonomous, so that he/she is not competent to make a decision that can be justified.
\end{abstract}

Keywords: paternalism, patient, doctor, competent

\begin{abstract}
Abstrak: Dalam konteks etika, paternalisme dimaksudkan setiap tindakan yang membatasi kebebasan seseorang tanpa persetujuannya, yang bertujuan mencegah terjadinya kerugian baginya, atau melakukan sesuatu yang baik, yang tidak dapat diperolehnya dengan cara lain. Prinsip paternalisme perlu dibedakan dengan prinsip kerugian. Prinsip paternalisme mengatakan bahwa kebebasan seseorang boleh dibatasi, jika orang itu akan merugikan dirinya sendiri karena kelakuannya sendiri, atau tidak akan memperoleh sesuatu yang sangat baik bagi dirinya. Sedangkan prinsip kerugian mengatakan bahwa kebebasan seseorang boleh dibatasi untuk melindungi orang lain dari kerugian. Di bidang pelayanan medis, paternalisme dapat menimbulkan konflik antara prinsip berbuat baik dan prinsip otonomi bila dokter mengambil tindakan medis tertentu atas dasar prinsip berbuat baik (the principle of beneficence) tanpa memberi informasi kepada pasien yang kompeten, atau hanya menyampaikannya kepada pihak keluarga. Dalam kondisi seperti ini tak ada informed consent atau informed choice dari pihak pasien, dan paternalisme ini tak dapat dibenarkan. Namun terdapat situasi di mana paternalisme tidak menimbulkan konflik antara kedua prinsip etika ini, yakni apabila pasien memang tidak otonom sehingga tidak kompeten untuk mengambil suatu keputusan rasional yang dapat dipertanggungjawabkan.
\end{abstract}

Kata kunci: paternalisme, pasien, dokter, kompeten

Paternalisme dalam tindakan medis dewasa ini menjadi problem karena penerapannya dalam hubungan dokter-pasien cenderung mengorbankan salah satu prinsip penting dalam etika biomedis yaitu prinsip otonomi (the principle of autonomy). Problem ini muncul seiring dengan kesadaran manusia akan otonominya yang berhak menentukan diri sendiri (self/auto-determination). Dalam hubungan dokter-pasien sikap paternalistis dinyatakan dalam sikap dokter yang tidak memberi informasi yang dibutuhkan 
kepada pasien menyangkut tindakan medis yang hendak ditempuh sehingga di sini tidak ada informed consent atau informed choice. Persoalannya, apakah paternalisme di bidang pelayanan medis selalu salah, padahal sikap paternalistis ini sesungguhnya bersumber dari prinsip etika biomedis yang lain yaitu prinsip berbuat baik (the principle of beneficence)? Apakah terdapat kondisi tertentu dari pasien yang membolehkan dokter mengambil sikap paternalistis tanpa melanggar prinsip otonomi? Dalam konteks ini terdapat pihak-pihak tertentu yang cenderung menghormati otonomi pasien dengan intervensi persuasif bilamana pasien memilih tindakan yang merugikan dirinya, sementara yang lain cenderung melindungi pasien terhadap kemungkinan munculnya konsekuensi yang merugikan dari pilihan mereka. Intervensi dokter dalam pengambilan keputusan itulah yang menjadi problem paternalisme.

\section{PENGERTIAN "PATERNALISME"}

Kata "paternalisme" berasal dari kata sifat bahasa Latin "paternalis", yang berarti "kebapaan" atau "sebagai seorang bapak". Dasar kata ini adalah kata Latin "pater" yang berarti "bapak". Karena itu paternalisme dipakai untuk setiap tingkah laku yang memperlakukan seseorang seolah-olah dia seorang anak. Paternalisme berpegang teguh pada semboyan "father knows best", dan pernah menjadi judul suatu seri film televisi terkenal di Amerika Serikat. Istilah ini dilatarbelakangi suasana patriarkal, karena hanya memikirkan tingkah laku seorang bapak. Sebetulnya parentalisme adalah istilah yang lebih tepat (berasal dari parens, orang tua). Namun karena istilah paternalisme sudah terlanjur digunakan, maka cukuplah bila kita menyetujui bahwa seorang wanita pun dapat bertindak dengan cara amat paternalistis.

Dalam konteks etika, kata paternalisme biasanya dipakai dalam arti lebih sempit yang menunjukkan setiap tindakan yang membatasi kebebasan seseorang tanpa persetujuannya dengan maksud atau mencegah kerugian bagi dia atau melakukan sesuatu yang baik, yang tidak dapat diperolehnya dengan cara lain. Kalimat ini boleh dianggap sebagai definisi paternalisme sebagaimana dimaksudkan dalam konteks pelayanan medis. ${ }^{1,2}$

The Oxford English Dictionary mengartikan paternalisme sebagai sikap mengabaikan keinginan atau tindakan seseorang atas dasar prinsip kebaikan. Jika keinginan atau tindakan seseorang tidak bersumber dari suatu putusan yang bebas (autonomous choice) namun mengekspresikan maksudnya (intention), maka sikap mengabaikan keinginan atau tindakannya adalah sikap paternalistik yang dapat dibenarkan. "Intervensi paternalistik" tidak selalu berarti pengabaian prinsip otonomi. Dalam banyak kasus secara moral dapat dibenarkan pembatasan kebebasan seseorang bila penggunaan kebebasannya dapat mengakibatkan kerugian bagi orang lain. Prinsip ini dikenal sebagai prinsip kerugian (the harm principle). ${ }^{3}$

\section{PRINSIP KERUGIAN}

Tindakan paternalistis diambil berdasarkan prinsip paternalistis. Prinsip paternalistis mengatakan bahwa kebebasan seseorang boleh dibatasi, jika orang itu akan merugikan dirinya sendiri karena kelakuannya sendiri atau tidak akan memperoleh sesuatu yang sangat baik bagi dirinya. Dalam hal ini prinsip paternalistis harus dibedakan dengan prinsip kerugian (the harm principle), yang juga membatasi kebebasan seseorang. Prinsip kerugian mengatakan bahwa kebebasan seseorang boleh dibatasi untuk melindungi orang lain terhadap kerugian. Misalnya, berdasarkan prinsip kerugian seorang pasien dengan gangguan jiwa dapat dikurung dalam klinik bila tingkah lakunya menimbulkan bahaya untuk orang lain. Cukup banyak aturan dan undang-undang yang sebenarnya didasarkan atas prinsip paternalistis. Contoh yang berlaku umum ialah peraturan menggunakan helm untuk pengemudi sepeda motor atau menggunakan sabuk pengaman bagi pengemudi mobil yang kini diberlakukan di Indonesia. Etika kedokteran sering berhadapan 
dengan kasus-kasus di mana prinsip paternalistis diterapkan. Beberapa contoh lainnya, seperti memberikan transfusi darah kepada seorang yang telah menolaknya karena keyakinan religiusnya, menolak mengikutsertakan seorang sukarelawan dalam suatu eksperimen biomedis karena resikonya terlalu besar, banyak jenis terapi dalam klinik psikiatris, menghentikan percobaan bunuh diri orang yang telah melakukannya dengan sadar dan rasional, mereanimasi seorang pasien yang sebelumnya telah minta supaya tidak akan direanimasi, dan sebagainya. ${ }^{1,3}$

\section{PRINSIP OTONOMI DAN PRINSIP BERBUAT BAIK}

Prinsip paternalistis ini merupakan lanjutan dari prinsip yang lebih fundamental dalam etika yaitu prinsip "berbuat baik" (principle of beneficence). Namun dalam hal paternalisme, prinsip berbuat baik itu diterapkan dengan mengorbankan prinsip otonomi. Oleh karena itu paternalisme menimbulkan konflik antara dua prinsip yaitu prinsip otonomi dan prinsip berbuat baik. Menurut Immanuel Kant (1724-1804) dan kaum deontolog, menghormati sesama berarti membiarkannya sebagai individu bebas untuk membuat pertimbangan sendiri dan bertindak sesuai pilihannya (dalam batas-batas moral tertentu). "Hormat" ini muncul dari kesadaran bahwa semua orang memiliki nilai diri yang tak bersyarat dan tujuan dalam dirinya sendiri. Dengan demikian intersubyektivitas harus dijiwai sikap saling menghormati. ${ }^{4,5}$

Dalam konteks pelayanan medis, menurut prinsip otonomi, seorang dokter harus menghormati otonomi pasien, dan ia harus memperlakukan orang dewasa sebagai orang dewasa dan tidak sebagai anak. Dokter wajib memberikan informasi lengkap kepada pasien, dan tidak boleh memaksakan suatu keputusan pada pasien. Setelah memperoleh segala informasi yang diperlukan, pasien berhak mengambil keputusan terakhir tentang semua hal yang menyangkut dirinya, termasuk juga tindakan medis. Oleh karena itu dalam rangka prinsip otonomi, selama pasien sendiri masih sanggup menerima informasi dan mengambil keputusan, tidaklah cukup bila informasi diberikan kepada keluarga saja, dan keputusan diambil oleh anggota keluarga. Mengandalkan keputusan keluarga (misalnya menandatangani surat izin operasi) jelas merupakan suatu tindakan paternalistis. Menurut prinsip kedua (the principle of beneficence), seorang dokter harus melakukan yang terbaik bagi pasiennya. Dalam sumpah Hippokrates telah dicantumkan janji dokter bahwa ia akan menghindari segala sesuatu yang merugikan pasien. "I will apply dietetic measures for the benefit of the sick according to my ability and judgment; I will keep them from harm and injustice" (The Hippocratic Oath). Seandainya pasien menghendaki sesuatu yang merugikan dirinya sendiri, hal ini berarti bahwa ia tidak rasional. Bila pasien diperlakukan secara paternalistis, maka kelak ia akan berterima kasih setelah ia insaf dan dapat melihat masalahnya menurut proporsi yang wajar. ${ }^{1,3,4}$

\section{PATERNALISME DAN INFORMED CONSENT}

William David Ross (1879-1971) mengusulkan jalan keluar bila menghadapi konflik kewajiban. Ross menyusun sebuah daftar kewajiban yang kesemuanya merupakan kewajiban prima facie yakni (1) kewajiban kesetiaan, (2) kewajiban ganti rugi, (3) kewajiban terima kasih, (4) kewajiban keadilan, (5) kewajiban berbuat baik, (6) kewajiban mengembangkan diri, dan (7) kewajiban tidak merugikan. Dalam etika biomedis terdapat empat prinsip yang mewajibkan setiap dokter dalam tindakan medisnya yakni 1) principle of autonomy, (2) principle of beneficence, (3) principle of nonmaleficence, dan (4) principle of justice. Ketiga prinsip terakhir ini adalah sama dengan yang disebutkan oleh Ross di atas. ${ }^{3}$

Dalam pelayanan kesehatan dapat terjadi konflik sehubungan dengan sikap paternalistis dokter yang bertindak atas dasar kewajibannya untuk berbuat baik bagi pasiennya, tetapi dengan itu ia melanggar 
otonomi pasien. Konflik ini muncul berkenaan dengan masalah informed consent. Dalam hal ini perlu dipertimbangkan kompetensi pasien yaitu kesanggupan untuk mengambil keputusan tentang pengobatan dengan mempertimbangkan semua faktor yang relevan, memahami prosedur, mempertimbangkan resiko dan manfaat, serta dapat mengambil keputusan sesuai pengetahuannya dan nilai-nilai serta tujuan yang hendak dicapai. Keputusan rasional ini dibuat berdasarkan informasi yang cukup lengkap yang diberikan oleh dokter sehingga dari pihak pasien ada informed consent atau informed choice, walaupun dapat juga terjadi bahwa kompetensi dikurangi karena ketakutan, kebingungan atau keadaaan emosi pasien. Namun dokter pun jangan terlalu cepat menganggap pasien tidak kompeten. Sejauh mana kompetensi pasien untuk mengambil keputusan tergantung pada pemahamannya akan informasi dan komunikasi antara pasien dan dokter yang terjadi atas dasar kepercayaan. Sebaliknya paternalisme dapat dibenarkan apabila pasien tidak kompeten, dan karena itu persetujuan diminta dari keluarga/wali. Namun bila keluarga/wali tidak ada, atau pun bila hadir tetapi tidak kompeten juga, maka tim medis harus memutuskan sendiri tindakan medis yang harus ditempuh sesuai keadaan pasien. Informed consent tidak diperlukan dalam keadaan pasien kritis atau darurat yang membutuhkan tindakan medis secara cepat dan tepat sesuai kemampuan tenaga medis dan peralatan medis yang tersedia. Dalam situasi seperti ini dokter memutuskan sendiri untuk melakukan yang terbaik demi kepentingan pasien, yang dilakukan atas dasar prinsip beneficentia. ${ }^{3-8}$

\section{JENIS PATERNALISME}

Terdapat dua ciri sikap paternalistis: pertama, seorang ayah selalu menghendaki yang terbaik untuk anak-anaknya; dan kedua, selalu mengambil keputusan-keputusan yang berhubungan dengan kesejahtaraan anak-anaknya daripada membiarkan mereka membuat keputusan-keputusan sendiri. Dalam konteks pelayanan kesehatan secara profesional, paternalisme dibuat terutama berdasarkan prinsip beneficentia, daripada prinsip otonomi. Khususnya dalam hubungan dengan informed consent, terdapat dua prinsip yang diterapkan yakni: (1) Prinsip otonomi di mana pasien dimintakan persetujuannya setelah diberi informasi yang cukup, sebagai bentuk hormat akan otonominya yang berhak memutuskan apa yang dapat dibuat terhadapnya; (2) Prinsip perlindungan (the principle of protection), yaitu persetujuan dalam konteks medis yang berfungsi memaksimalkan kebaikan (keuntungan) dan meminimaliskan kerugian terhadap pasien. Prinsip ini cenderung membenarkan intervensi paternalistis atas pasien. Sedangkan sehubungan dengan prinsip nonmaleficentia, bila pemberitahuan tindakan medis tertentu secara langsung dapat merugikan pasien (dalam kasus penyakit terminal dan pasien emosional), maka informasi tak perlu disampaikan atas dasar prinsip "So far as possible, 'Do no harm", dan informasi cukup disampaikan kepada keluarga saja. ${ }^{3}$

Di antara para ahli etika terdapat dua pandangan tentang paternalisme. Ada yang dengan tegas menolak setiap tindakan paternalistis sebagai tidak etis, tetapi ada juga yang menerimanya sebagai sah, walaupun dengan syarat-syarat tertentu. Filsuf yang secara radikal menolak setiap bentuk paternalisme adalah John Stuart Mill (18061873) dalam buku kecilnya On Liberty. Mill berpendapat bahwa pilihan dan tindakan pelaku otonom tidak boleh dibatasi orang lain selama tidak merugikan orang dan/atau dirinya sendiri. Kebebasan seseorang hanya boleh dibatasi atas dasar prinsip kerugian, sedangkan prinsip paternalistis ditolaknya dengan tegas. Tetapi banyak yang berkomentar bahwa Mill mempunyai gagasan yang terlalu idealistis tentang kebebasan. Tidak jarang terjadi, seseorang berpikir bahwa ia bertindak dengan sadar dan bebas, tetapi kebebasannya terlalu di bawah tekanan batin atau pengaruh dari luar, sehingga tidak utuh. Hal ini misalnya sering terjadi pada orang yang berusaha bunuh diri. ${ }^{3}$

Joel Feinberg membedakan antara paternalisme kuat (strong paternalism) dan paternalisme lemah (weak paternalism). 
Paternalisme lemah adalah setiap tindakan yang menentang kemauan pasien yang tidak bebas atau tidak cukup bebas. Dalam hal ini prinsip otonomi tidak dilanggar, karena pasien dianggap tidak otonom. Misalnya, kemauan pasien yang belum mendapat informasi atau orang yang berusaha bunuh diri di bawah pengaruh obat bius. Sedangkan dengan paternalisme kuat dimaksudkan setiap tindakan yang mengalahkan kemauan pasien yang bebas. Bila pembedaan ini dapat disetujui, umumnya ahli etika akan menolak paternalisme kuat dan menerima paternalisme lemah dalam batas-batas tertentu. Pembedaan ini memang berguna, tetapi seringkali sulit ditentukan apakah kemauan pasien itu bebas atau tidak. Akibatnya sulit juga untuk menentukan apakah paternalisme yang dipraktekkan itu kuat atau lemah. ${ }^{1-3}$

\section{PEMBENARAN PATERNALISME}

Sikap paternalistis dapat diambil guna melindungi seseorang dari tindakan yang merugikan dirinya sendiri seperti eksperimen biomedis yang membahayakan dirinya. Dalam hal ini paternalisme hanya dapat dibenarkan jika: (1) mencegah kerugian yang akan terjadi atau kebaikan yang hendak dicapai bagi seseorang lebih besar daripada kehilangan kebebasannya, artinya kerugian lebih kecil daripada kebaikan yang diperoleh melalui intervensi paternalistik, (2) kondisi seseorang sungguh-sungguh membatasi kemampuannya untuk memilih secara otonom, seperti depresi, serta pengaruh alkohol atau obat bius, dan (3) keadaan pasien kritis atau darurat di mana tindakan medis harus diambil secara cepat dan tepat. Dalam hal ini para ahli etika memandang paternalisme sebagai suatu bentuk "kebijaksanaan jaminan sosial" (social insurance policy) guna melindungi orang-orang yang tindakannya dapat merugikan dirinya sendiri. ${ }^{3,4}$

Terdapat beberapa bidang konkrit di mana paternalisme sering dipraktekkan dalam dunia kedokteran. Dalam hal ini paternalisme dapat dibenarkan asal saja memenuhi syarat-syarat tertentu.

\section{Memberi placebo}

Bila diterjemahkan secara harafiah, kata Latin "placebo" (k.k. Latin placere, menyenangkan) itu berarti "saya akan menyenangkan hatimu". Dalam terminologi kedokteran, dengan placebo dimaksudkan pil, tablet atau minuman yang diberikan kepada pasien tetapi sebenarnya tidak mempunyai pengaruh atas penyakitnya, namun pasien percaya bahwa "obat" tersebut dapat membantu menyembuhkannya. Seringkali obat placebo itu hanya berupa pil gula atau vitamin. Memberi placebo sebetulnya dapat dianggap merupakan penipuan halus, karena pasien mengharapkan obat, padahal hanya diberikan gula atau vitamin. Pengaruh placebo bersifat psikis saja, walaupun pada kenyataannya cukup banyak penyakit mempunyai latar belakang psikosomatis, sehingga pasien mudah dipengaruhi secara psikis. Placebo tidak jarang bisa berhasil menghilangkan penyakit dan dapat dibenarkan dalam banyak situasi. Dalam hal ini seorang dokter harus berhati-hati dimana keluhan pasien jangan terlalu cepat dianggap tidak serius. Selain itu pemberian placebo jangan dijadikan jalan untuk menghindari diagnosis yang teliti dan tepat. ${ }^{1}$

\section{Tidak menceritakan kebenaran}

Bisa terjadi bahwa menyampaikan diagnosis yang benar lebih merugikan pasien daripada membantunya. Karena itu dapat saja dibenarkan bila dalam situasi tertentu dokter tidak menceritakan kebenaran kepada pasien. Pandangan ini berdasarkan argumen "benevolent deception" (penipuan yang baik). Artinya menyampaikan suatu diagnosis seperti kanker misalnya tidak akan melanggar kewajiban melakukan kebaikan (prinsip beneficene) dan tidak merugikan (nonmaleficence) bila tidak dilakukan, sebab tidak akan menyebabkan pasien gelisah (what you don't know can't hurt you), tidak menyebabkan pasien bunuh diri atau melakukan tindakan-tindakan serupa itu. Tetapi sikap tidak menceritakan kebenaran pada umumnya mengandaikan bahwa dokter mempunyai sikap sebagai psikolog atau sekurang-kurangnya mengenal baik sekali 
keadaan jiwa pasiennya. Perlu dicatat bahwa tindakan tidak menyampaikan kebenaran kepada pasien tidak selalu merupakan paternalisme dalam arti kata yang sesungguhnya. Dengan tidak menyampaikan kebenaran kepada pasien, seringkali sejalan dengan kemauan yang sesungguhnya dari pasien itu sendiri, yang tidak mau mendengar atau mengetahui kebenaran penyakitnya. 1,3

\section{Eksperimen pada manusia}

Di Amerika Serikat, 1976, National Commision for the Protection of Human Subjects of Biomedical and Behavioral Research mengeluarkan laporan yang berjudul Research involving Prisoners. Dalam laporan itu komisi mengatakan bahwa eksperimen-eksperimen yang dilakukan pada para tahanan tidak bisa dibenarkan walaupun mereka secara sukarela ikut serta. Alasannya adalah karena keadaan dalam penjara sedemikian rupa yang sangat memudahkan untuk menjalankan paksaan atau eksploitasi terhadap para tahanan tersebut. Dalam komentarnya atas laporan itu, Beauchamp menegaskan bahwa pandangan komisi tadi tidak perlu diinterpretasikan sebagai paternalistis, sebab komisi juga mengatakan bahwa seandainya keadaan tidak menimbulkan paksaan atau eksploitasi terhadap para tahanan, mereka tentu bebas untuk ikut serta dalam eksperimen-eksperimen tersebut. Komisi hanya menyatakan bahwa di kebanyakan lembaga pemasyarakatan Amerika Serikat situasi tidak demikian. Jadi sebenarnya komisi mendasarkan pendapatnya atas prinsip kerugian dan bukan atas prinsip patermalistis; mereka melarang pimpinan lembaga pemasyarakatan untuk merugikan pihak ketiga yaitu para tahanan. ${ }^{1-3}$

\section{FAKTOR HISTORIS-KULTURAL}

Keinsafan akan kebebasan merupakan suatu gejala modern yang baru muncul pada abad-18 (sekitar revolusi Prancis). Gagasan kebebasan mulai berkembang di dunia Barat, kemudian tersebar ke seluruh kawa- san. Hal ini terbukti dengan adanya Deklarasi Hak-Hak Asasi Manusia (1984) yang diterima oleh semua anggota PBB, di mana kebebasan individu merupakan suatu pikiran pokok. ${ }^{1,9}$

Di dunia Barat dewasa ini paternalisme ditolak lebih tegas, dan perkembangannya dalam jangka waktu yang relatif singkat. Dalam Kode Etik Perawatan 1953 dikatakan: "Kepercayaan keagamaan seorang pasien harus dihormati". Dua puluh tahun kemudian, yaitu tahun 1973 kalimat ini diganti dengan: "Dalam memberi pelayanan, seorang perawat memajukan suatu lingkungan di mana nilai-nilai, adat kebiasaan dan kepercayaan spiritual seseorang akan dihormati”. Jadi otonomi seseorang lebih ditekankan dalam perumusan kedua.,

Menyangkut masalah menceritakan kebenaran kepada pasien, dalam salah satu majalah kedokteran di Amerika Serikat tahun 1935 diberikan anjuran kepada para dokter: "Anda bisa merugikan pasien dengan menceritakan kebenaran, sama seperti berdusta. Cobalah menimbulkan kerugian sesedikit mungkin. Dewasa ini terdapat kecenderungan untuk lebih berhati-hati dalam menyembunyikan informasi untuk pasien. Para dokter sudah harus lebih terbuka terhadap pasien dan tidak mudah menyembunyikan kebenaran bagi dia. ${ }^{1,4}$

Dalam pelayanan medis di Indonesia informasi biasanya diberikan kepada keluarga. Dalam proses pengobatan dan penyembuhan, para dokter umumnya berkomunikasi dengan keluarga dan jarang langsung dengan pasien sendiri. Keadaan ini diterima oleh pasien dan keluarga sebagai hal yang lumrah. Jelaslah bahwa tampaknya paternalisme dalam pelayanan medis masih kuat di Indonesia bahkan merupakan pola tingkah laku yang cocok dengan kebudayaan Asia pada umumnya. Sebagai contoh, Rihito Kimura anggota staf pada Kennedy Institute of Ethics di Washington dan direktur dari Asian Bioethics Program di sana. Dalam Hasting Report tahun 1989 ia menulis sebuah artikel kecil berjudul: "In Japan, parents participate but doctors decide". Ia menjelaskan bahwa parents participate boleh saja dicoret karena sebenar- 
nya di Jepang para dokter menentukan segala sesuatu. Dalam artikel itu ia menulis: "Sebagai akibat nilai-nilai sosial dan relasirelasi manusiawi yang kuno, para dokter di Jepang sampai baru-baru ini bertindak dengan cara paternalistis dan otoriter terhadap pasien-pasien dan keluarganya. Para pasien juga cenderung mentaati dokter-dokter yang "berprestise". Tekanan pada individualitas yang unik seperti terdapat dalam dunia Barat, dianggap olehnya sebagai suatu unsur asing bagi masyarakat Jepang. Otonomi yang merupakan prinsip begitu penting dalam etika biomedis Barat, sebenarnya tidak mempunyai tempat dalam tradisi Jepang. Menonjolkan otonomi dan ketidaktergantungan di sana justru mempunyai konotasi negatif dan disamakan dengan egoisme. Yang menarik, penulis itu mengatakan juga bahwa pendekatan paternalistis dalam pengambilan keputusan di bidang medis semakin diragukan oleh pasien-pasien Jepang dan anggota keluarganya. Nyatalah bahwa dalam masyarakat Jepang pun terdapat suatu tendensi yang dalam arti Barat boleh disebut "modern". 1,9

\section{SIMPULAN}

Paternalisme dalam pelayanan medis menjadi problem sehubungan dengan adanya informed consent yang penerapannya dapat menimbulkan konflik antara prinsip beneficentia dan prinsip otonomi. Dalam situasi tertentu paternalisme dapat menguntungkan pasien seperti pada pasien depresi, gangguan jiwa, kritis/darurat, atau anakanak. Disini dokter mengambil sikap paternalistis dalam tindakan medis semata-mata demi kepentingan terbaik pasiennya (prinsip beneficentia). Dalam hal pasien tidak kompeten, tidak terjadi konflik antara prinsip berbuat baik dan prinsip otonomi. Demikian pula terhadap pasien emosional dokter dapat mengambil sikap paternalistis dengan tidak menceritakan kebenaran seiring dengan kemauan pasien untuk tidak mendengar kebenaran penyakitnya (paternalisme lemah). Sedangkan paternalisme kuat tetap tidak dapat dibenarkan karena melanggar otonomi pasien yang kompeten.

Paternalisme dalam pelayanan medis masih mengikuti pola-pola tingkah laku yang terdapat dalam masyarakat, antara lain sosial budaya, tingkat intelektual dan juga sifat pasien sendiri. Harus disadari bahwa cepat atau lambat paternalisme ini akan memudar dengan sendirinya sesuai tuntutan zaman.

\section{DAFTAR PUSTAKA}

1. Bertens K. Apa itu Paternalisme dan Sejauh Mana Dapat Dibenarkan. Seri Etika Biomedis 1986;1:1-13.

2. Beauchamp TL, Childress JF. Encyclopedia of Bioethics (Vol.III). New York: The Free Press-Collier Macmillan Publishers, 1978.

3. Beauchamp TL, Childress JF. Principles of Biomedical Ethics (Second Edition). New York: Oxford University Press, 1983.

4. Beauchamp TL, Childress JF. Philosophical Ethics, an Introduction to Moral Philosophy. New York: McGraw-Hill, 1982.

5. Bertens K. Etika. Seri Filsafat Atmajaya 1993;15:258-60.

6. Griese ON. Catholic Identity in Health Care: Principles and Practice. Massachusetts: The Pope John Center, 1987.

7. Gunawan J. Kelalaian Medik (Medical Negligence) (Edisi Kedua). Jakarta: Balai Penerbit FKUI, 1994.

8. Shannon TA. Pengantar Bioetika. Seri Filsafat Atmajaya 1995:16:20-33.

9. Bertens K. Mencari Tema-Tema Bioetika dalam Konteks Indonesia, dalam Bioetika, Refleksi atas Masalah Etika Biomedis. Jakarta: PT. Gramedia, 1990. 